\title{
Selective Degeneration of Entorhinal-CA1 Synapses in Alzheimer's Disease via Activation of DAPK1
}

\author{
Shu Shu, ${ }^{1,5}$ Houze Zhu, ${ }^{1,5}$ Na Tang, ${ }^{1,5}$ Wenting Chen, ${ }^{1,5}$ Xinyan Li, ${ }^{1,5}$-Hao Li, ${ }^{1,5}$ Lei Pei, ${ }^{2,5}$ Dan Liu, ${ }^{3,5}$ Yangling Mu, \\ Qing Tian, ${ }^{4,5}$ Ling-Qiang Zhu, ${ }^{4,5}$ and (DYouming $\mathrm{Lu}^{1,5}$ \\ 1Department of Physiology, School of Basic Medicine and Tongji Medical College, Huazhong University of Science and Technology, Wuhan 430030, China, \\ ${ }^{2}$ Department of Neurobiology, School of Basic Medicine and Tongji Medical College, Huazhong University of Science and Technology, Wuhan 430030, \\ China, ${ }^{3}$ Department of Genetics, School of Basic Medicine and Tongji Medical College, Huazhong University of Science and Technology, Wuhan 430030, \\ China, ${ }^{4}$ Department of Pathophysiology, School of Basic Medicine and Tongji Medical College, Huazhong University of Science and Technology, Wuhan \\ 430030, China, and 5Institute for Brain Research, Collaborative Innovation Center for Brain Science, Huazhong University of Science and Technology, \\ Wuhan 430030, China
}

Excitatory pyramidal neurons in the entorhinal cortical layer II region $\left(\mathrm{ECII}_{\mathrm{PN}}\right)$ form functional excitatory synapses with $\mathrm{CA} 1$ parvalbumin inhibitory neurons $\left(\mathrm{CA1}_{\mathrm{PV}}\right)$ and undergo selective degeneration in the early stages of Alzheimer's disease (AD). Here, we show that death-associated protein kinase 1 (DAPK1) is selectively activated in ECII $_{\mathrm{PN}}$ of AD mice. Inhibition of DAPK1 by deleting a catalytic domain or a death domain of DAPK1 rescues the $\mathrm{ECII}_{\mathrm{PN}}-\mathrm{CA}_{\mathrm{PV}}$ synaptic loss and improves spatial learning and memory in $\mathrm{AD}$ mice. This study demonstrates that activation of DAPK1 in $\mathrm{ECII}_{\mathrm{PN}}$ contributes to a memory loss in $\mathrm{AD}$ and hence warrants a promising target for the treatment of AD.

Key words: Alzheimers' disease; DAPK1; learning and memory; synaptic degeneration

\section{Significance Statement}

Our recent study reported that excitatory pyramidal neurons in the entorhinal cortical layer II region (ECII $\left.{ }_{\mathrm{PN}}\right)$ target to CA1 parvalbumin-type inhibitory neurons $\left(\mathrm{CAl}_{\mathrm{PV}}\right)$ at a direct pathway and are one of the most vulnerable brain cells that are selectively degenerated in the early stage of Alzheimer's disease (AD). Our present study shows that death-associated protein kinase 1 (DAPK1) is selectively activated in $\mathrm{ECII}_{\mathrm{PN}}$ of AD mice. Inhibition of DAPK1 by deleting a catalytic domain or a death domain of DAPK1 rescues the $\mathrm{ECII}_{\mathrm{PN}}-\mathrm{CA} 1_{\mathrm{PV}}$ synaptic loss and improves spatial learning and memory in the early stage of AD. These data not only demonstrate a crucial molecular event for synaptic degeneration but also provide a therapeutic target for the treatment of AD.

\section{Introduction}

Alzheimer's disease (AD) is the most common form of dementia in the elderly, affecting $>10$ million people in China and $>35$

Received July 15, 2016; revised Aug. 19, 2016; accepted Aug. 30, 2016.

Author contributions: Y.L., S.S., W.C., H.Z., N.T., and D.L. designed research; S.S., W.C., H.Z., N.T., X.L., H.L., L.P., and D.L. performed research; Y.L., S.S., W.C., H.Z., N.T., X.L., H.L., L.P., D.L., Y.M., Q.T., and L.-Q.Z. analyzed data;Y.L., S.S., W.C., H.Z., N.T., D.L., Y.M., Q.T., and L.-Q.Z. wrote the paper.

This work was supported by the National Natural Science Foundation of China Grants 81130079 to Y.L., 91232302 to Y.L. 81571078 to L.P., 31571039 to L.-Q.Z., Top-Notch Young Talents Program of China of 2014, and Academic Frontier Youth Team of HUST to L.-Q.Z. We thank Dr. Hengye Man (Boston University) for comments on the manuscript.

The authors declare no competing financial interests.

This article is freely available online through the J Neurosci Author Open Choice option.

Correspondence should be addressed to either Dr. Ling-Qiang Zhu or Dr. Youming Lu, Tongji Medical College, Huazhong University of Science and Technology, Wuhan 430030, China. E-mail: zhulq@hust.edu.cn or lym@hust.edu.cn.

DOI:10.1523/JNEUROSCI.2258-16.2016

Copyright $\odot 2016$ Shu et al.

This is an Open Access article distributed under the terms of the Creative Commons Attribution License Creative Commons Attribution 4.0 International, which permits unrestricted use, distribution and reproduction in any medium provided that the original work is properly attributed. million people worldwide. The deposition of senile plaques that primarily consist of amyloid- $\beta(\mathrm{A} \beta)$ peptide is a major pathological hallmark in the brains of $\mathrm{AD}$ patients and has long been considered to be associated with a progressive loss of central neurons in certain regions of the brain (Tanzi et al., 1987; Goate et al., 1991; Jack et al., 2010; Duffy et al., 2015). However, recent studies have shown that impairments in learning and memory, the early clinical signs of $\mathrm{AD}$, are caused by synaptic dysfunction rather than neuronal cell loss. For example, in $\mathrm{AD}$ patients, cognitive decline is closely associated with a reduction in the number of presynaptic glutamatergic terminals (Gomez-Isla et al., 1996; Kamenetz et al., 2003; Oddo et al., 2003). Tg2576-APPswe mice (AD mice), which carry a transgene encoding the 695 amino acid isoform of the human $A \beta$ precursor protein with the Swedish mutation and exhibit plaque pathologies similar to those in $\mathrm{AD}$ patients, show decays in synaptic transmission and impairments in spatial learning and memory in an age-dependent manner (Chapman et al., 1999; Jacobsen et al., 2006; Scheff et al., 2007). 
However, which of the many synapses in the brain undergo selective degeneration during the early stages of $\mathrm{AD}$ and whether this selective degeneration contributes directly to the loss of spatial learning and memory are still unknown.

Excitatory pyramidal neurons in the entorhinal cortex (EC, $\mathrm{EC}_{\mathrm{PN}}$ ), which primarily target to the hippocampus, are the most vulnerable brain cells in the early stages of AD (Hsia et al., 1999; Yassa, 2014; Yang et al., 2016). The $\mathrm{EC}_{\mathrm{PN}_{\mathrm{N}}}$ are largely distributed in the EC layer II (ECII $\mathrm{PN}_{\mathrm{PN}}$ ) and III (ECIII $\left.{ }_{\mathrm{PN}}\right)$ regions. These neurons innervate excitatory pyramidal neurons and parvalbumin (PV) inhibitory GABA-containing neurons in the CA1 hippocampus $\left(\mathrm{CA} 1_{\mathrm{PV}}\right)$ and are associated with spatial and temporal associative memories (Kitamura et al., 2014; Yang et al., 2016). Our recent study showed that amyloid deposition occurs in the brain of $\mathrm{AD}$ mice at 8 months of age, whereas synaptic transmission between $\mathrm{ECII}_{\mathrm{PN}}$ and $\mathrm{CA} 1_{\mathrm{PV}}$ undergoes degeneration at 6 months of age (Yang et al., 2016). This finding indicates that synaptic degeneration is not associated with the presence of amyloid plagues. Yet, the molecular mechanisms underlying degeneration of $\mathrm{ECII}_{\mathrm{PN}}$ synapses remain unknown. Our present studies demonstrate that death-associated protein kinase 1 (DAPK1) became activated selectively in the $\mathrm{ECII}_{\mathrm{PN}}$ of $\mathrm{AD}$ mice. We show that activation of DAPK1 is responsible for a selective degeneration of $\mathrm{ECII}_{\mathrm{PN}^{-}}$ $\mathrm{CA1} 1_{\mathrm{PV}}$ synapses and that inhibition of DAPK1 is therapeutically effective for the intervention of spatial learning and memory declines in $\mathrm{AD}$.

\section{Materials and Methods}

Animals. All mice used in this study were bred and reared under the same conditions in the University's core animal facility in accordance with institutional guidelines and the Animal Care and Use Committee (Huazhong University of Science and Technology, Wuhan, China). The mice were housed in groups of 3-5 per cage and maintained with a $12 \mathrm{~h}$ light-dark cycle, with lights on at 8:00 A.M., at consistent ambient temperature $\left(22 \pm 1^{\circ} \mathrm{C}\right)$ and humidity (50 $\pm 5 \%)$. Tg2576-APPswe mice (the $\mathrm{AD}$ mice), which expressed a mutant form of $A \beta$ precursor protein (APP) (isoform 695) with the Swedish mutation (KM670/671NL), were purchased from the The Jackson Laboratory. In the present study, all the AD mice were identified as homozygous. Male mice were used in this study.

Generation of the mutant mice. To generate the $\mathrm{AD} / E C I I_{P N} C h R 2+$ mice, we expressed ChR2-eGFP in the $\mathrm{ECII}_{\mathrm{PN}}$ of mutant mice that had a loxPflanked STOP sequence followed by ChR2 (E123A)-eGFP. The RosaCAG-Flag-ChR2eGFP-WPRE targeting vector was designed with a CMV-IE enhancer/chicken $\beta$-actin/rabbit $\beta$-globin hybrid promoter (CAG), an FRT site, a loxP-flanked STOP cassette, a Flag-eGFP sequence, a woodchuck hepatitis virus post-transcriptional regulatory element (WPRE; to enhance the mRNA transcript stability), a poly-A signal, and an attB/att-flanked PGK-FRT-Neo-poly-A cassette. This entire construct was inserted into the Gt(ROSA)26Sor locus via electroporation into C57BL/6-derived embryonic stem (ES) cells. The targeted ES cells were selected and injected into C57BL/6 blastocysts, and chimeric animals were then bred to $\mathrm{C} 57 \mathrm{BL} / 6$ mice $\left(\mathrm{ChR} 2^{\operatorname{lox} P / l o x P}\right)$.

Next, we created the rAAV1/2-D28K-Cre virus particles. We designed the rAVE- $D 28 K$-Cre vector by inserting a Cre recombinase sequence immediately downstream of the calbindin 1 (or calbindin-D28K, D28K) translational STOP codon via Apal/Kpnl. The rAVE plasmids were cotransfected with AAV helper $1 / 2$ mixers into HEK293 cells to generate rAAV1/2-D28K-Cre virus particles with a high titer $\left(>5 \times 10^{12}\right.$ genomic particles/ml), as described previously (Tu et al., 2010; Pei et al., 2015; Yang et al., 2016). The virus particles $(1.5 \mu \mathrm{l})$ were bilaterally injected into the EC superficial layer (anteroposterior $4.8 \mathrm{~mm}$, mediolateral $2.8 \mathrm{~mm}$, dorsoventral 3.5-4.0 mm) in the $\mathrm{AD} / \mathrm{ChR} 2^{\text {loxP } / \text { loxP }}$ and control/ChR2 $2^{\text {loxP } / \text { loxP }}$ mice, thus leading to ChR2-eGFP expression in the $\mathrm{ECII}_{\mathrm{PN}}$ of the $\mathrm{AD}$ or control mice (AD/ECII ${ }_{P N} C h R 2+$ and control/ECII ${ }_{P N} C h R 2+$ mice).

To generate the $\mathrm{AD} / E C I I_{P N}{ }^{C D-}$ mice, we first created a mutant strain of mice with selective deletion of the catalytic domain (CD) of DAPK1
(DAPK1 ${ }^{\text {CDloxPlloxP }}$ mice) by targeting the exon 2 region, as described previously (Pei et al., 2015). The DAPK1 ${ }^{\text {CDloxP/loxP }}$ mice were crossed with the $\mathrm{AD} / E C I I_{P N}{ }^{C h R 2+}$ mice, thus resulting in $\mathrm{AD} / E C I I_{P N}{ }^{C D-}$ mice, in which the DAPK1 CD was selectively deleted in the $\mathrm{ChR} 2{ }^{+}-\mathrm{ECII}_{\mathrm{PN}}$. To generate the $\mathrm{AD} / E C I I_{P N}{ }^{D D-}$ mice, we created a mutant strain of mice with a selective deletion of the death domain (DD) of DAPK1 (DAPK1 $1^{\text {DDloxP/loxP }}$ mice). In brief, an FRT-flanked Neo resistance positive selection cassette was inserted downstream of exon 27; one loxP site was introduced upstream of exon 26 and another loxP site was introduced downstream of the Neo cassette. After linearization, the targeting vector was transfected into C57BL/6J embryonic stem cells via electroporation. Six positive clones were identified by Southern blotting with a $5^{\prime}$ probe, a $3^{\prime}$ probe, and a Neo probe. Two positive clones were injected into BALB/c blastocysts and implanted into pseudopregnant females. Chimeric mice were crossed with C57BL/6J mice to obtain F1 mice carrying the recombined allele containing the floxed DAPK1 allele and the Neo selection cassette. These mice were mated with Flp recombinaseexpressing C57BL/6J Flp mice to remove the Neo resistance cassette and to generate a line of Neo-excised DAPK1 $1^{\text {DDloxP/loxP }}$ mice. When these mice were bred with the $\mathrm{AD} / E C I I_{P N} C h R 2+$ mice, the offspring were $\mathrm{AD} /$ $E C I I_{P N}{ }^{D D-}$ mice, in which the DAPK1 DD was selectively deleted in the $\mathrm{ChR} 2^{+}-\mathrm{ECII}_{\mathrm{PN}}$

Single-cell Western blots, kinase assays, and coimmunoprecipitation. $\mathrm{EC}$ tissues were isolated from the $\mathrm{AD} / E C I I_{P N} \operatorname{ChR2}+$ mice, the $\mathrm{AD} /$ $E C I I_{P N}{ }^{C D-}$ mice, the $\mathrm{AD} / E C I I_{P N}{ }^{D D-}$ mice and their respective controls and sliced and digested in buffer containing $10 \mathrm{~mm}$ Tris-Cl, $\mathrm{pH}$ 7.6, 50 $\mathrm{mm} \mathrm{NaF}, 1 \mathrm{~mm} \mathrm{Na} \mathrm{VO}_{4}, 1 \mathrm{~mm}$ edetic acid, $1 \mathrm{~mm}$ benzamidine, $1 \mathrm{~mm}$ PMSF, $1 \mathrm{mg} / 10 \mathrm{ml}$ papain, and a mixture of aprotinin, leupeptin, and pepstatin A $(10 \mu \mathrm{g} / \mathrm{ml}$ each) for $30 \mathrm{~min}$. The cell suspension of ECII $_{\mathrm{PN}}{ }^{\text {eGFP }+}$ was automatically isolated using an S3e Cell Sorter (Bio$\mathrm{Rad})$. The isolated $\mathrm{ECII}_{\mathrm{PN}}$ were homogenized and diluted with a buffer containing $200 \mathrm{~mm}$ Tris-Cl, pH 7.6, 8\% SDS, and 40\% glycerol. The protein concentration was determined using a BCA kit (Pierce). Final concentrations of $10 \% \beta$-mercaptoethanol and $0.05 \%$ bromophenol blue were added, and the samples were boiled for $10 \mathrm{~min}$ in a water bath. The proteins in the extracts were separated by $10 \%$ SDS-PAGE and transferred to nitrocellulose membranes. The blots were scanned by using an Infrared Imaging System (Odyssey, LI-COR). The blots were incubated with antibodies against DAPK1 (1:500, Epitomics, catalog\#3798-1). The band densities were quantitatively analyzed by using Kodak Digital Science 1D software (Eastman Kodak).

Immunocomplex kinase assay was used to determine the catalytic activity of DAPK1 in the lysates and myosin light chain (MLC) that was phosphorylated at Ser-18/Thr-20 ( $p$ MLC) by activated DAPK1 was blotted with anti-pMLC (1:1000, Millipore). The enzymatic activity of DAPK1 was expressed as the ratio of $p$ MLC to DAPK1 protein under the same conditions. Immunoprecipitation was used to determine the association of DAPK1 with its substrates. The lysates ( $\sim 200 \mu$ g protein) were incubated with nonspecific IgG $(2 \mu \mathrm{g})$ or polyclonal rabbit anti-DAPK1 antibody ( $2 \mu \mathrm{g}$, Millipore) overnight at $4^{\circ} \mathrm{C}$, and this was followed by the addition of $40 \mu \mathrm{l}$ of Protein G-Sepharose (Sigma) and incubation for $3 \mathrm{~h}$ at $4^{\circ} \mathrm{C}$. The precipitates were washed four times with lysis buffer, denatured with SDS sample buffer, and separated by $12 \%$ SDS-PAGE. The proteins were transferred onto nitrocellulose membranes using a BioRad mini-protein-III wet transfer unit overnight at $4^{\circ} \mathrm{C}$. The transferred membranes were then incubated with blocking solution $[5 \%$ nonfat dried milk dissolved in TBST buffer containing $10 \mathrm{~mm}$ Tris- $\mathrm{HCl}, 150 \mathrm{~mm}$ $\mathrm{NaCl}$, and $0.1 \%$ Tween 20 for $1 \mathrm{~h}$ at room temperature, washed three times, and incubated with anti-goat primary antibody against Tau (1: 1000, Santa Cruz Biotechnology), anti-rabbit antibody against Erk (1: 1000; Millipore), or anti-DAPK1 (1:1000, Sigma) for $1 \mathrm{~h}$ at room temperature. The membranes were washed three times with TBST buffer, incubated with the appropriate secondary antibodies (1:1000 dilution) for $1 \mathrm{~h}$, and washed four times. Signal detection was performed with an enhanced chemiluminescence kit (GE Healthcare). The lanes marked "input" were loaded with $10 \%$ of the starting material used for immunoprecipitation.

Electrophysiology. Brain slices $(300 \mu \mathrm{m})$ were prepared as previously described (Tu et al., 2010; Pei et al., 2015; Yang et al., 2016). The slices were transferred to a holding chamber containing ACSF consisting of 124 
mм NaCl, $3 \mathrm{~mm} \mathrm{KCl}, 26 \mathrm{~mm} \mathrm{NaHCO}, 1.2 \mathrm{~mm} \mathrm{MgCl}_{2} \cdot 6 \mathrm{H}_{2} \mathrm{O}, 1.25 \mathrm{~mm}$ $\mathrm{NaH}_{2} \mathrm{PO}_{4} \cdot 2 \mathrm{H}_{2} \mathrm{O}, 10 \mathrm{~mm} \mathrm{C}_{6} \mathrm{H}_{12} \mathrm{O}_{6}$, and $2 \mathrm{~mm} \mathrm{CaCl}_{2}, \mathrm{pH} 7.4$ and 305 $\mathrm{mOsm}$. The slices were allowed to recover at $31.5^{\circ} \mathrm{C}$ for $30 \mathrm{~min}$ and then at room temperature for $1 \mathrm{~h}$. Acute slices were transferred to a recording chamber continuously perfused with oxygenated ACSF $(2 \mathrm{ml} / \mathrm{min})$ and maintained at room temperature. For whole-cell patch-clamp recordings from the $C A 1_{\mathrm{PV}}$, brain slices from the $\mathrm{AD}$ mice, in which mCherry was expressed in the $C A 1_{\mathrm{PV}}$ cells, were visualized via fluorescence IR-DIC using an Axioskop 2FS equipped with Hamamatsu C2400-07E optics. When stable whole-cell recordings were achieved with good access resistance $(\sim 20 \mathrm{M} \Omega)$, basic electrophysiological properties were recorded. All the data were acquired at $10 \mathrm{kHz}$ and filtered with a $2 \mathrm{kHz}$ low-pass filter. The evoked EPSCs were recorded in the slices by delivering blue laser light ( $5 \mathrm{~ms}, 405$-nm-wavelength laser at power densities ranging from 0.1 to $5 \mathrm{~mW} / \mathrm{mm}^{2}$ ) directly onto the $\mathrm{ECII}_{\mathrm{PN}}$, which had normal intrinsic properties in $\mathrm{AD} / E C I I_{P N} \operatorname{ChR2+}$ (resting membrane potentiation = $69.3 \pm 2.1 \mathrm{mV}$; input resistance $=386 \pm 21 \mathrm{M} \Omega$, mean $\pm \mathrm{SEM}, n=36$ cells/ 6 mice), $\mathrm{AD} / E C I I_{P N}{ }^{C D-}$ (resting membrane potentiation $=68.7 \pm$ $2.0 \mathrm{mV}$; input resistance $=389 \pm 19 \mathrm{M} \Omega$, mean $\pm \mathrm{SEM}, n=33$ cells $/ 5$ mice), and $\mathrm{AD} / E C I I_{P N}{ }^{D D-}$ mice (resting membrane potentiation = $69.9 \pm 1.9 \mathrm{mV}$; input resistance $=401 \pm 17 \mathrm{M} \Omega$, mean $\pm \mathrm{SEM}, n=39$ cells $/ 5$ mice) when they were at $180 \pm 5 \mathrm{~d}$ of age, compared with the age-matched controls (resting membrane potentiation $=70.1 \pm 1.7 \mathrm{mV}$; input resistance $=403 \pm 13 \mathrm{M} \Omega$, mean $\pm \mathrm{SEM}, n=32$ cells $/ 5$ mice).

Extracellular single-unit recording. Extracellular single-unit and local field power spectrum recordings were made from the CA1 neurons (anteroposterior $-1.7 \mathrm{~mm}$, mediolateral $1.0 \mathrm{~mm}$, and dorsoventral $0.5-0.8$ $\mathrm{mm}$ target to CA1). Mice were connected to the recording equipment via AC-coupled unity-gain operational amplifiers (Plexon). Signals were amplified 4000- to 8000-fold. The spikes and local field potentials were recorded simultaneously and isolated by using a $250 \mathrm{~Hz}$ low-pass filter and a $250 \mathrm{~Hz}$ high-pass filter and the commercial software OmniPlex (Plexon). Spike sorting was performed off-line using graphical clustersorting software (Offline Sorter, Plexon). To estimate the quality of the cluster separation, we calculated the isolation distance and the L-ratio using Plexon SDK. Only the units with an L-ratio $<0.05$ and a distance $>15$ were included.

To isolate and analyze spike units from individual $C A 1_{\mathrm{PN}}$ versus the $\mathrm{CAl}_{\mathrm{PV}}$, we calculated the valley-to-peak time and the half-width of the spikes. Spikes from $\mathrm{CA} 1_{\mathrm{PN}}$ were identified and distinguished from those of $C A 1_{I N}$ according to the duration of the negative spike, the firing pattern (complex spikes), and the low average firing rate. Spikes from $\mathrm{CA} 1_{\mathrm{PV}}$ were validated as described previously (Yang et al., 2016). The average firing rate was expressed as the total number of spikes divided by the total length of the recording period.

Morris Water Maze. A pool $1.5 \mathrm{~m}$ in diameter was filled with water that was made opaque with white nontoxic ink and maintained at $25.0^{\circ} \mathrm{C}$. Animals were brought to the behavior room (where they were housed for the duration of the training), handled for 1-2 d, and trained, as described previously (Tu et al., 2010; Pei et al., 2015; Yang et al., 2016). The entire protocol lasted $7 \mathrm{~d}$. The first training day consisted of a probe trial followed by a "visible platform" trial, in which the platform was indicated by a red flag. Next, mice were subjected to their first "hidden platform" learning trial, during which they were allowed to rest on the platform for $30 \mathrm{~s}$ before being released from one of the pool's starting points (north, south, east, or west). The animals were allowed $60 \mathrm{~s}$ to find the platform and were allowed to stay there for $30 \mathrm{~s}$; if an animal did not find the platform within $60 \mathrm{~s}$, it was removed from the water and placed on the platform for $30 \mathrm{~s}$. During days 1-6, four trials were performed corresponding to the four different randomized release points. Therefore, the total training took $6 \mathrm{~d}$ followed by a final $24 \mathrm{~h}$ probe on the seventh day.

Open-field tests and rotarod tests. Locomotor activity was assessed in clear boxes measuring $100 \mathrm{~cm} \times 100 \mathrm{~cm}$ that were outfitted with photobeam detectors for monitoring horizontal and vertical activity, as described previously (Tu et al., 2010; Pei et al., 2015; Yang et al., 2016). The data were collected using a PC and were analyzed using the MED Associates Activity Monitor Data Analysis software. Mice were placed in a corner of the open-field apparatus and allowed to move freely. The variables recorded included resting time (seconds), ambulatory time (sec- onds), vertical/rearing time (seconds), jump time (seconds), stereotypic time (seconds), and average velocity (centimeters per second). The mice were not exposed to the chamber before testing. The data were recorded for each animal during $30 \mathrm{~min}$ intervals. For the rotarod test, mice were subjected to a 1 week learning period, after which they were able to perform on an accelerating rotarod. The test was then performed twice per week until the mice were unable to remain on the rotating bar for $>10 \mathrm{~s}$ in three consecutive attempts, which was defined as rotarod failure.

Data analysis. All variance values in the text and figure legends are represented as the mean \pm SEM. Parametric tests, including $t$ tests and two-way ANOVAs, were used when assumptions of normality and equal variance ( $F$ test) were met; two-way repeated-measures ANOVA was used to analyze the Morris Water Maze data. Differences were considered statistically significant when $p<0.05$.

\section{Results}

\section{Activation of DAPK1 in $\mathrm{ECII}_{\mathrm{PN}}$ of AD mice}

To determine the molecular mechanisms underlying the selective degeneration of $\mathrm{ECII}_{\mathrm{PN}}$ synapses in $\mathrm{AD}$ mice, we focused our studies on DAPK1, an enzyme critical for synaptic losses in central neurons (Tu et al., 2010). To functionally and morphologically identify individual $\mathrm{ECII}_{\mathrm{PN}}$, we generated $\mathrm{AD} / E C I I_{P N} \mathrm{ChR2+}$ mice, in which channelrhodopsin-2-E123A (ChR2), a modified version of a light-gated cation channel, and an eGFP were selectively expressed in the vulnerable $\mathrm{ECII}_{\mathrm{PN}}$ of the $\mathrm{AD}$ mice. $\mathrm{A}$ mouse model of AD was chosen because these mice carry a transgene coding for the 695 amino acid isoform of the human Alzheimer $A \beta$ precursor protein with the Swedish mutation and exhibit plaque pathologies similar to those in $\mathrm{AD}$ patients.

Specifically, we created a conditional line of mutant mice that expressed a double-floxed inverted open reading frame of ChR2-eGFP (ChR2 ${ }^{\text {loxP/loxP }}$ mice; Fig. $\left.1 A\right)$. We also constructed a Type $1 / 2$ recombinant adeno-associated (rAAV1/2)-D28K-Cre virus vector, in which Cre recombinase was expressed under the control of the $D 28 \mathrm{~K}$ promoter (Fig. $1 B$ ). Virus particles at high titer were injected directly into the ECII of the $\mathrm{AD} / \mathrm{ChR} 2^{\text {loxP } / \text { loxP }}$ mice, resulting in the ChR2-eGFP expression specifically in the $\mathrm{ECII}_{\mathrm{PN}}$ (Fig. $1 B$ ). $\mathrm{ECII}_{\mathrm{PN}}$ cells were named as island cells, in which Wfs 1 is expressed (Kitamura et al., 2014). Consistent with this previous study, we showed that $\mathrm{ECII}_{\mathrm{PN}}$ that directly innervate $\mathrm{CA} 1_{\mathrm{PV}}$ were labeled with an antibody against $\mathrm{Wfs} 1$ protein (Fig. $1 C)$. Thus, $\mathrm{ECII}_{\mathrm{PN}}{ }^{\mathrm{ChR} 2+}$ neurons comprise a group of excitatory island cells.

We next isolated $\mathrm{ECII}_{\mathrm{PN}}{ }^{\mathrm{ChR} 2+}$ cells from the brain tissues of the $\mathrm{AD} / E C I I_{P N}{ }^{C h R 2+}$ mice using flow cytometry and cell sorting techniques. To determine the catalytic activity of DAPK1 in the purified $\mathrm{ECII}_{\mathrm{PN}}{ }^{\mathrm{ChR} 2+}$ cells, we applied an immunocomplex kinase assay with MLC as an endogenous substrate of DAPK1 (Tu et al., 2010). We precipitated DAPK1 protein complex in the cell lysates of the ECII ${ }_{\mathrm{PN}}{ }^{\mathrm{ChR} 2+}$ cells from the $\mathrm{AD} / E C I_{P N} \mathrm{ChR2+}$ mice and the controls (the control/ECII ${ }_{P N}^{C h R 2+}$ mice) using an antibody against DAPK1. The precipitates were then blotted with antibodies against a pMLC and DAPK1, respectively (Fig. 1D). Our data revealed that the levels of $p M L C$ were increased in the $\mathrm{ECII}_{\mathrm{PN}}{ }^{\mathrm{ChR} 2+}$ cells from the $\mathrm{AD} / E C I I_{P N}{ }^{C h R 2+}$ mice after $150 \mathrm{~d}$ of age (Fig. 1D), compared with the age-matched control/ $E_{C I I}{ }_{P N} C h R 2+$ mice (Fig. 1E). The $p M L C$ was catalyzed by an activated DAPK1 as MLC kinase (MLCK) that also targets MLC at serine-20 was undetectable in the precipitates from the ECII $_{\mathrm{PN}}{ }^{\mathrm{ChR} 2+}$ cells of the AD/ECII ${ }_{P N}{ }^{\mathrm{ChR} 2+}$ mice (Fig. $\left.1 F\right)$. An increase of the $p \mathrm{MLC}$ was found in the $\mathrm{ECII}_{\mathrm{PN}}{ }^{\mathrm{ChR} 2+}$ cells only, but not in the frontal cortical neurons from the $\mathrm{AD} / E C I I_{P N} \operatorname{ChR2+}$ 

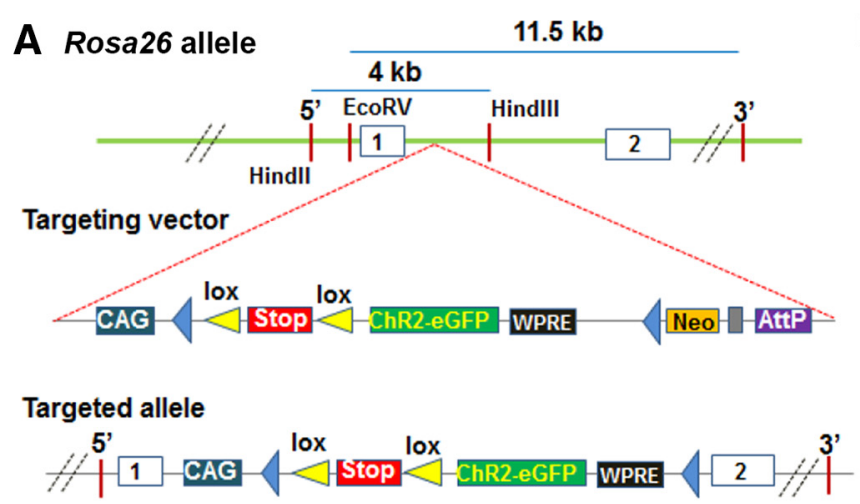

B

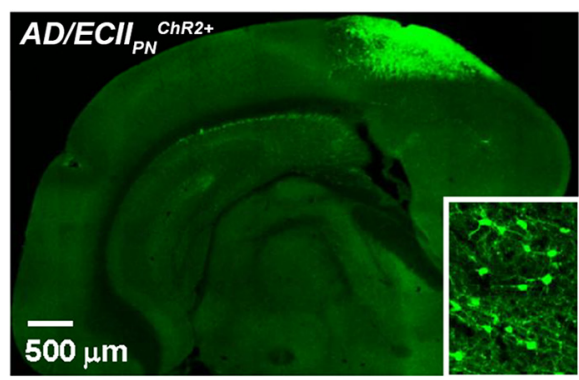

\section{ADIECII ${ }_{P N}{ }^{C h R 2+}$ mice}
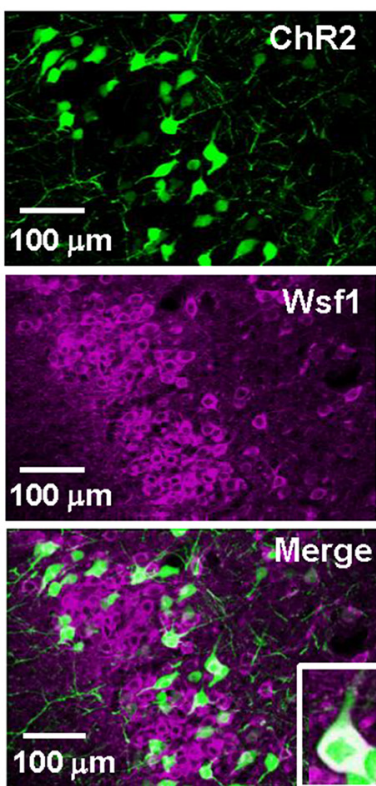

D $\quad A D / E C l I_{P N}{ }^{C h R 2+}$ mice
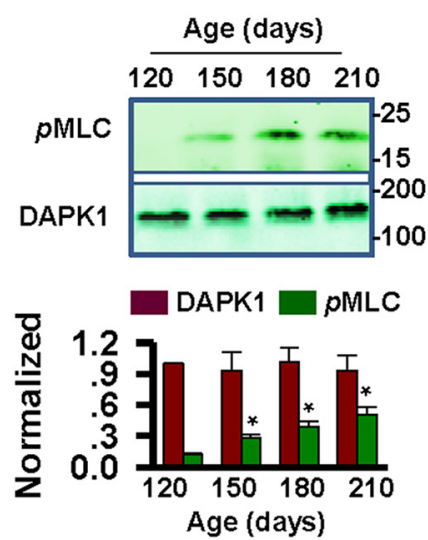

$\mathbf{F}$

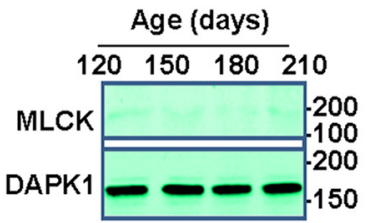

E Control/EClI ${ }_{P N}{ }^{C h R 2+}$ mice

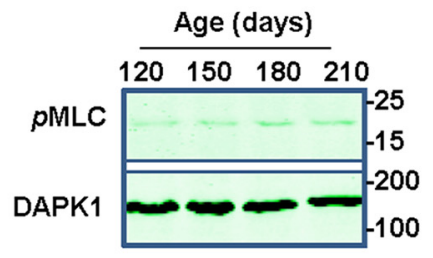

DAPK1 $\square$ pMLC

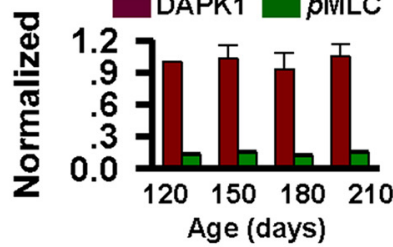

G

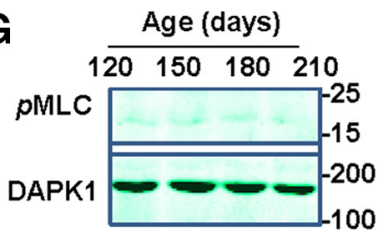

Figure 1. DAPK1 as activated specifically in $\mathrm{EC} \|_{P N}$ of AD mice. $A$, Illustration of the targeting vector used to generate the ChR2-eGFPloxP/loxP mice. $B$, Representative image showing the selective expression of ChR2-eGFP in $\mathrm{ECll}_{\mathrm{PN}}$ of $\mathrm{AD} / \mathrm{ECCl} \mathrm{PN}^{\mathrm{C} R 2+}$ mice when the rAAV1/2-D28K-Cre virus particles were stereotaxically injected into the ECII region. $C$, Representative images indicating that the $E C \|_{P N}{ }^{C h R 2+}$ are labeled with an antibody against the Wsf1 protein. Similar results were seen in each of the four experiments. D,E, DAPK1 becomes activated in ECCI ${ }_{P N}$ of $A D$ mice at $150 \mathrm{~d}$ of age. The ECIII ${ }_{P N}{ }^{c h R 2+}$ cells were isolated from the brain sections of the AD/ECII ${ }_{P N}^{\text {ChR2+ }}$ mice $(\boldsymbol{D})$ and the control/ECIIIN ${ }_{P N}^{\text {ChR2 }+}$ mice $(\boldsymbol{E})$, respectively, when they were at 120, 150, 180, and 210 d of age. The cell lysates were then prepared from the isolated ECII ${ }_{P N}$ ChR2+ cells and precipitated with anti-DAPK1. The precipitates were blotted with antibodies against $p M L C$ or DAPK1, as indicated. In bar graphs, the band intensity was normalized to that of the DAPK1 protein from a mouse at $120 \mathrm{~d}$ of age (defined as 1.0$)$. Data are mean $\pm S E M(n=5) .{ }^{*} p<0.001(t$ tests). $\boldsymbol{F}, \boldsymbol{G}$, the $p M L C$ is catalyzed

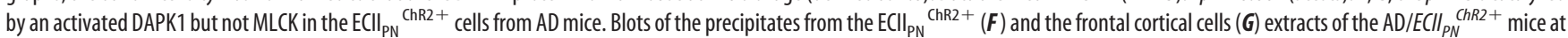
$120,150,180$, and $210 \mathrm{~d}$ of age with antibodies against MLCK, pMLC, or DAPK1, as indicated. Similar results were seen in each of the four experiments.

mice (Fig. 1G). Together, these data demonstrate that DAPK1 is activated selectively in $\mathrm{ECII}_{\mathrm{PN}}$ cells of $\mathrm{AD}$ mice during aging.

Genetic inhibition of DAPK1 in ECII ${ }_{\mathrm{PN}}$ of AD mice

We next determined whether activation of DAPK1 in the $\mathrm{ECII}_{\mathrm{PN}}$ of $\mathrm{AD}$ mice contributes to impairments in synaptic transmission along the $\mathrm{ECII}_{\mathrm{PN}^{-}}-\mathrm{CAl}_{\mathrm{PV}}$ pathway. We developed two independent approaches to inhibiting DAPK1 function in the $\mathrm{ECII}_{\mathrm{PN}}$ of $\mathrm{AD}$ mice. First, we generated a mutant strain of mice $\left(D A P K 1^{\text {CDloxPloxP }}\right)$ in which a double-floxed inverted open reading frame of DAPK1 with a $\mathrm{CD}$ deletion was expressed (Fig. $2 A, B$ ). When these mice were bred with $\mathrm{AD} / \mathrm{ECII}_{P_{N}}^{\mathrm{ChR2}+}$ mice, which Cre recombinase was expressed in the $\mathrm{ECII}_{\mathrm{PN}}{ }^{\mathrm{ChR2}+}$ cells (for details, see Fig. 1B), the CD of DAPK1 (DAPK1 ${ }^{\mathrm{CD}-}$ ) was selectively deleted in the $\mathrm{ECII}_{\mathrm{PN}}{ }^{\mathrm{ChR2}}{ }^{+}$of the offspring (AD/ECII ${ }_{P N}^{C D-}$ mice; Fig. $\left.2 C-E\right)$. To verify the suc- cessful generation of $\mathrm{AD} / E C I I_{P N}{ }^{C D-}$ mice, we performed two independent lines of the studies. First, we stained the sections from the $\mathrm{AD} / E C I I_{P N}{ }^{C D-}$ mice with antibody against $D 28 \mathrm{~K}$ protein and showed that the DAPK1 ${ }^{\mathrm{CD}-}$ mutant protein in the $\mathrm{ECII}_{\mathrm{PN}}{ }^{\mathrm{ChR} 2+}$ cells was recognized by anti- $D 28 K$ (Fig. $2 D$ ). Second, we isolated the $\mathrm{ECII}_{\mathrm{PN}}{ }^{\mathrm{ChR} 2+}$ cells from the $\mathrm{AD} / E C \mathrm{EII}_{P N}{ }^{C D-}$ mice using flow cytometry and cell sorting techniques. The cell lysates were prepared from the isolated $\mathrm{ECII}_{\mathrm{PN}}{ }^{\mathrm{ChR} 2+}$ cells and precipitated with anti-DAPK1. The precipitates were blotted with antibodies against $p$ MLC and DAPK1 proteins, as indicated (Fig. 2E). Our data revealed a complete loss of DAPK1 enzymatic activity in the $\mathrm{ECII}_{\mathrm{PN}}{ }^{\mathrm{ChR} 2+}$ cells of the $\mathrm{AD} / E C I I_{P N}{ }^{C D-}$ mice (Fig. $2 E$ ).

Next, we generated the mutant mice (DAPK1 $1^{\text {DDloxP/loxP }}$ mice) in which a double-floxed inverted open reading frame of DAPK1 lacking a DD was expressed (Fig. $2 F, G$ ). When these mice were 

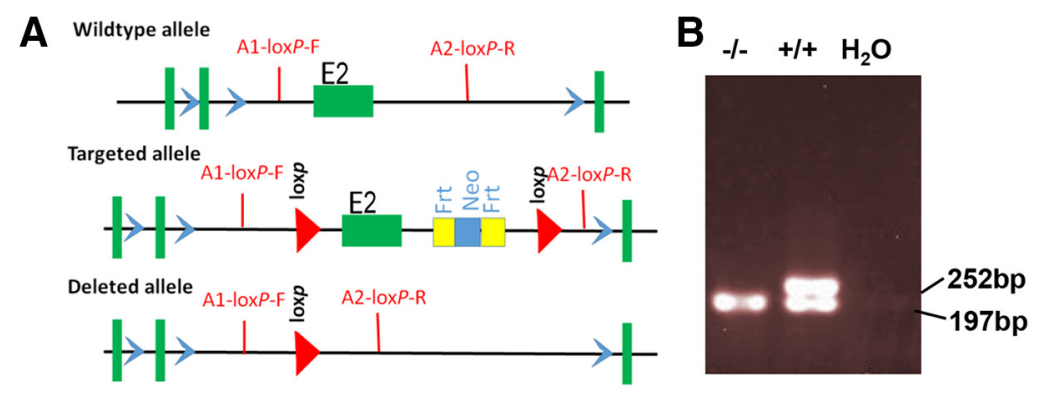

C Tg3 and $A D / E C I I_{P N}{ }^{C D}$.mice

1. ChR $2^{\text {loxP/loxP }}$ mice

2. AD mice

\section{DAPK1 $1^{\text {CDloxP/loxP }}$ mice}

4. rAAV1/2-D28K-Cre
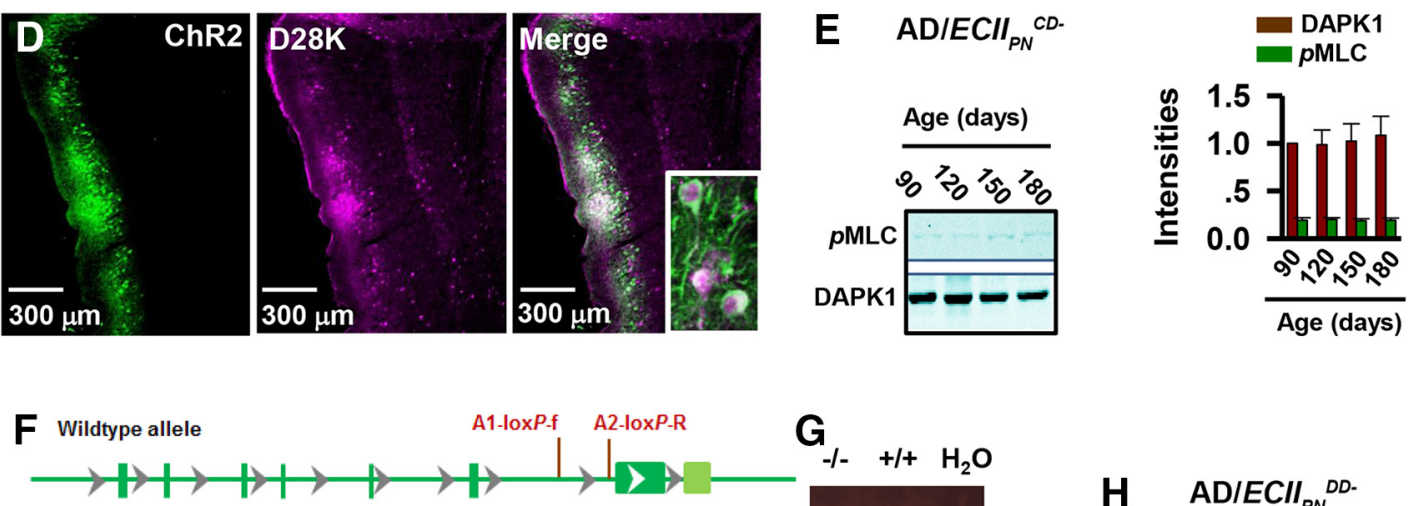

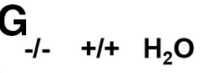
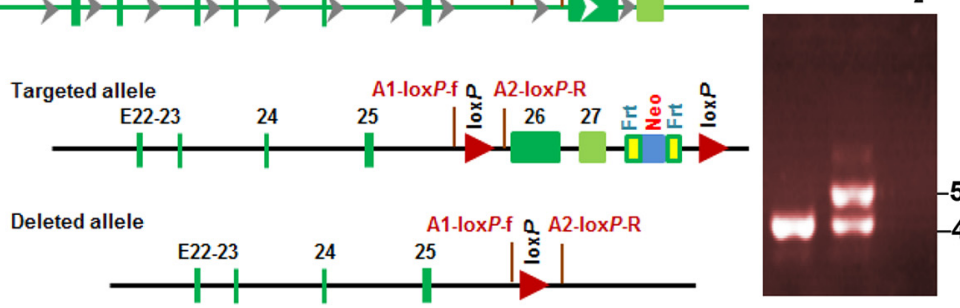

H

$\mathrm{AD} / E C I_{P N}{ }^{D D}-$

I
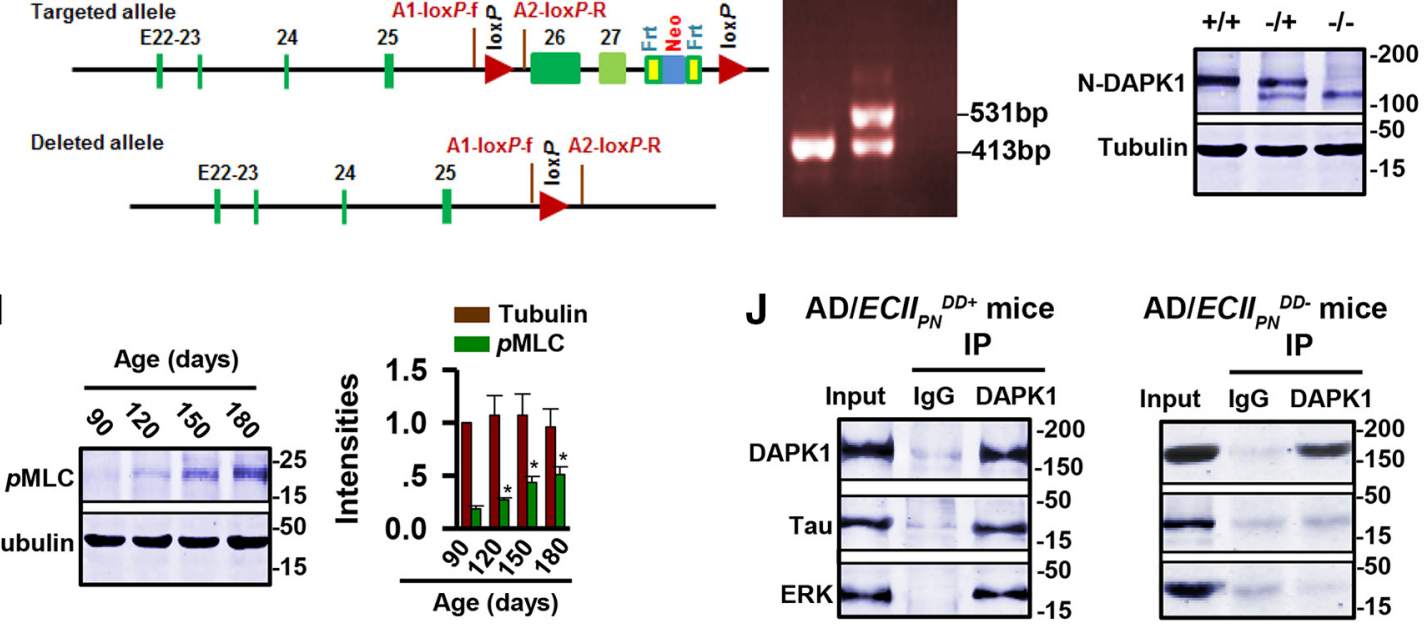

Figure 2. Genetic inhibition of DAPK1 in ECCII ${ }_{P N}$ of AD mice. $A$, Constructs for the generation of DAPK 1 CDloxP/loxP mice. $B$, Representative PCR showing the expression of the mutant transcripts in the $D A P K 1^{\text {CDloxP/loxP }}$ mice. C, The Tg3 mice were generated by crossing the ChR2 ${ }^{\text {loxP/IOxP }}$ mice with the AD mice and the DAPK $7^{\text {CDloxP/loxP }}$ mice and were stereotaxically injected with the rAAV1/2-D28K-Cre virus particles into the $E C C l$ region, resulting in the $A D / E C I_{P N}{ }^{C D-}$ mice. $D$, Representative images showing the $E C \|_{P N}$ from the $A D / E C I_{P N}{ }^{C D-}$ mice that expressed the DAPK1 ${ }^{C D-}$ mutant protein (green, ChR2) and that were stained with an antibody against the D28K protein (pink). Similar results were seen in each of the five experiments. $E$, Blots of the ECII $\|_{P N}$ extracts from the AD/ECII ${ }_{P N}{ }^{C D-}$ mice using antibodies against $p M L C$ or DAPK1, as indicated. The band intensity was normalized to that of the DAPK1 protein from mice at $90 \mathrm{~d}$ of age (defined as 1.0). Data are mean \pm SEM $(n=5) . F$, Constructs for the generation of the DAPKI ${ }^{\text {DDoxP/loxP }}$ mice. $\boldsymbol{G}, \boldsymbol{H}$, Representative images showing the expression of mutant transcripts $(\boldsymbol{G})$ and protein $(\boldsymbol{H})$ from the $D A P K{ }^{D D l o x P / l o x P}$ mice. $\boldsymbol{H}$, An antibody against the N-terminal region of DAPK1 (N-DAPK1) recognizes the wild-type $(\sim 160 \mathrm{kDa})$ and mutant proteins $(\sim 140 \mathrm{kDa})$. Similar results were seen in each of the five experiments. I, Deletion of the DAPK1 $D D$ does not affect the catalytic activity of DAPK1. Blots of the $E C \|_{P N}$ extracts from the AD/ECII ${ }_{P N}{ }^{D D-}$ mice using antibodies against $p M L C$ or N-DAPK1, as indicated. The band intensity was normalized to that of the N-DAPK1 protein from mice at $90 \mathrm{~d}$ of age (defined as 1.0$)$. Data are mean \pm SEM $(n=5)$. J, Deletion of the DAPK1 DD inhibits the association of DAPK1 protein with its substrates. The $E C \|_{P N}$ cell lysates from the $A D / E C I_{P N}{ }^{D+}\left(D D^{+}\right)$or the $A D / E C I_{P N}{ }^{D D-}\left(D D^{-}\right)$mice were precipitated with nonspecific lgG or antibodies against DAPK1. The precipitates were then blotted with antibodies against N-DAPK1, Tau protein, or ERK protein, as indicated. Input: $10 \mu \mathrm{g}$ of protein from the ECII ${ }_{\text {PN }}$ cell lysates without precipitation was loaded. Similar results were seen in each of the four experiments.

crossed with the $\mathrm{AD} / E C I I_{P N} C h R 2+$ mice, the DD of DAPK1 was selectively deleted (DAPK1 ${ }^{\mathrm{DD}-}$ ) in the $\mathrm{ECII}_{\mathrm{PN}}{ }^{\mathrm{ChR} 2+}$ of the offspring $\left(\mathrm{AD} / E C I I_{P N}{ }^{D-}\right.$ mice). The successful expression of DAPK $1{ }^{\text {DD- }}$ mutant protein was confirmed by blotting the cell lysates from the ECII ${ }_{\mathrm{PN}}{ }^{\mathrm{ChR} 2+}$ cells of the $\mathrm{AD} / E C I I_{P N}{ }^{D-}-$ mice with antibody against N-terminal fragment of DAPK1 (N-DAPK1; Fig. $2 H)$. We next examined the enzymatic activity of DAPK $1^{\mathrm{DD}-} \mathrm{mu}-$ tant protein. We isolated the $\mathrm{ECII}_{\mathrm{PN}}{ }^{\mathrm{ChR} 2+}$ cells from the $\mathrm{AD} /$ $E C I I_{P N}{ }^{D D-}$ mice using flow cytometry and cell sorting techniques. The cell lysates were prepared from the isolated ECII ${ }_{\mathrm{PN}}{ }_{\mathrm{ChR} 2+}$ cells and precipitated with anti-DAPK1. The precipitates were blotted with antibodies against $p$ MLC, tubulin, Tau, and ERK proteins, as indicated (Fig. 2I,J). Our data revealed that the expression of DAPK $1^{\mathrm{DD}-}$ did not alter the catalytic activity of DAPK1 (Fig. 2I), 

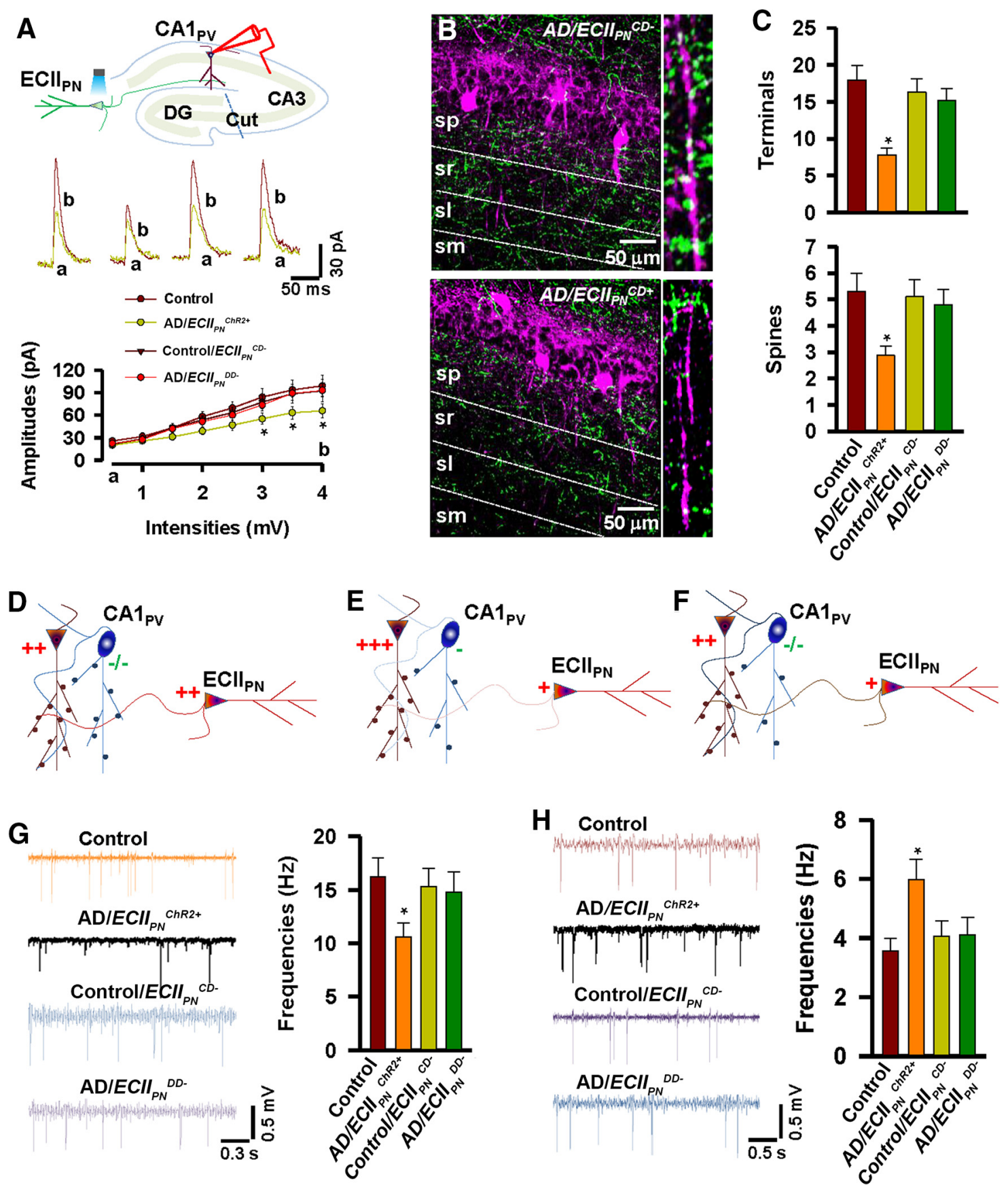

Figure 3. Inhibition of DAPK1 protects against the $E C \|_{P N}-C A 1_{P V}$ synaptic decay in AD mice. $A$, Illustration (top) represents the recording configurations. The mean amplitudes of the evoked NMDA receptor EPSCs in the $C A 1_{P V}$ at a holding potential of $60 \mathrm{mV}$ are plotted versus the light intensity increments $\left(0.5 \mathrm{mV}\right.$ intervals) of stimulation of $E C \mathrm{II}_{\mathrm{PN}}{ }^{\mathrm{ChR2}+}$. Data are mean \pm SEM ( $n=25$ recordings $/ 5$ mice/group). ${ }^{*} p<0.001$ ( $t$ tests). Representative recordings above the graph are the average of 12 sweeps of the evoked EPSCs at the low (a) and high (b) stimulus intensities. $\boldsymbol{B}$, Representative images show the ChR2-eGFP-labeled terminals (green) of the ECIII ${ }_{\text {PN }}$ in the CA1 hippocampus stained with anti-PV antibody (pink). $C$, Bar graphs represent the numbers (terminals $/ 0.2 \mathrm{~cm}^{2}$ ) of the ChR2-eGFP-labeled terminals in the stratum lacunosum-moleculare region and the PV-labeled spines (spines/10 $\mu \mathrm{m}$ dendritic branches) in the stratum lacunosum-moleculare region. Data are mean \pm SEM $\left(n=5\right.$ mice/group). ${ }^{*} p<0.001$ (t tests). $\boldsymbol{D}-\boldsymbol{F}$, A working model showing that inhibition of DAPK1 restores excitatory and inhibitory balance in the CA1 circuits of $A D$ mice. Under the physiological conditions $(\boldsymbol{D})$, ECII ${ }_{P N}$ form direct excitatory synapses with $C A 1_{P V}$ and balance the excitatory/ inhibitory synaptic transmission in $C A 1$ circuits. During the disease progression of $\mathrm{AD}(\boldsymbol{E}), \mathrm{E}\left(\mathrm{II}_{\mathrm{PN}}-\mathrm{CA} 1_{\mathrm{PV}}\right.$ synapses are degenerated. This degeneration disables the excitatory and inhibitory balance as a consequence of a loss of inhibitory inputs from $C A 1_{P V}$ to $C A 1_{P N}$. Inhibition of DAPK1 in the $E C I_{P N}(F)$ effectively intervenes in the degeneration of $E C_{P N}-C A 1_{P V}$ synapses and restores the excitatory and inhibitory synaptic balance in AD mice. $\boldsymbol{G}, \boldsymbol{H}$, Genetic inhibition of DAPK1 restores the balance between excitation and inhibition in $C A 1_{\mathrm{PV}}(\boldsymbol{G})$ and $C A 1_{\mathrm{PN}}(\boldsymbol{H})$ cells of $A D$ mice at $180 \mathrm{~d}$ of age. Representative recordings of spike units of $C A 1$ neurons in freely moving mice. The spikes in $C A 1_{P V}(\boldsymbol{G})$ versus $C A 1_{P N}(\boldsymbol{H})$ were isolated based on the valley-to-peak time and the half-width of the spikes. The averaged frequencies of action potential firings of $C A 1_{P V}(\boldsymbol{G})$ and $C A 1_{P N}(\boldsymbol{H})$ in freely moving mice at $180 \mathrm{~d}$ of age were summarized in bar graphs. Data are mean \pm SEM ( $n=11$ mice per group). ${ }^{*} p<0.001$ ( $t$ tests). 

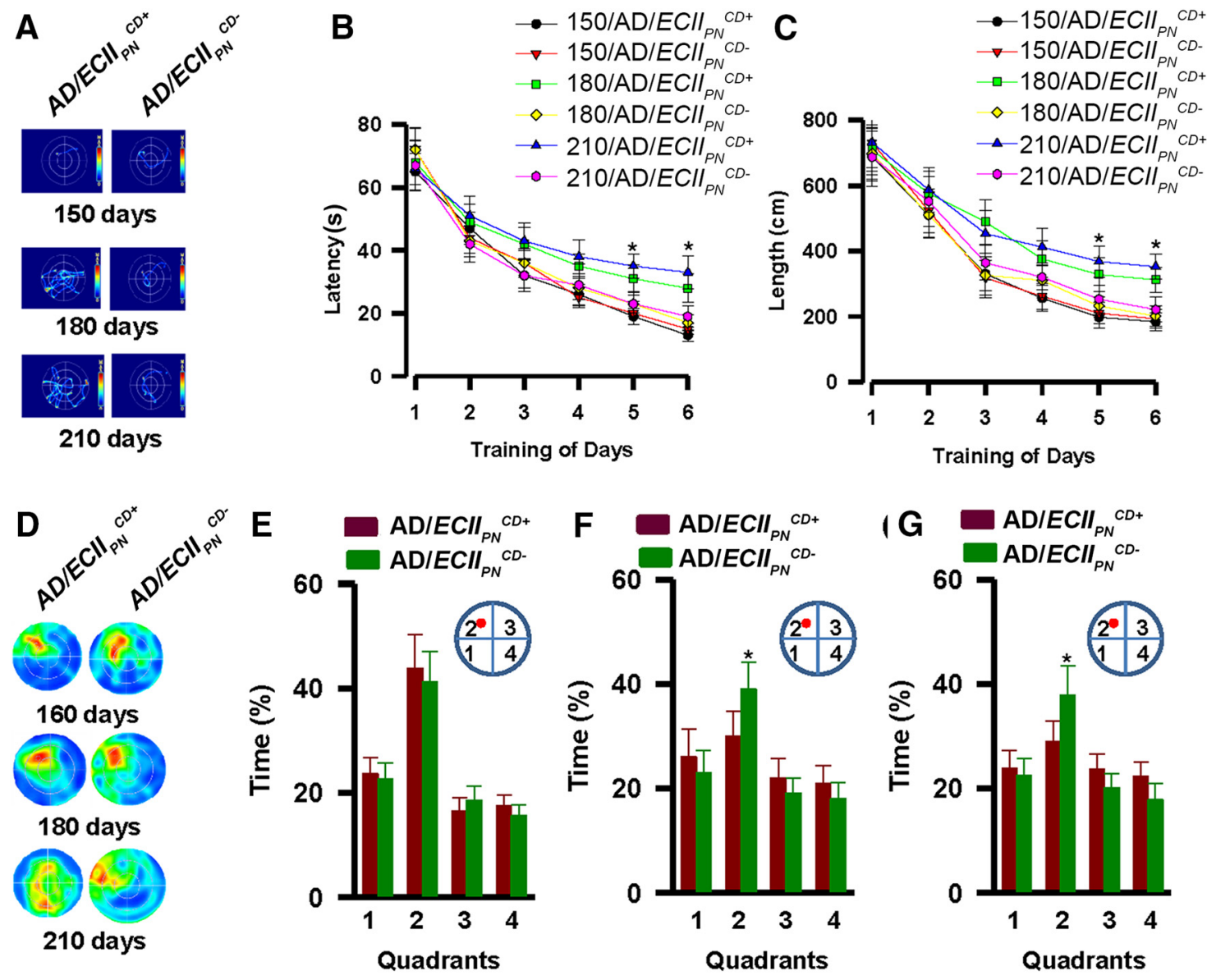

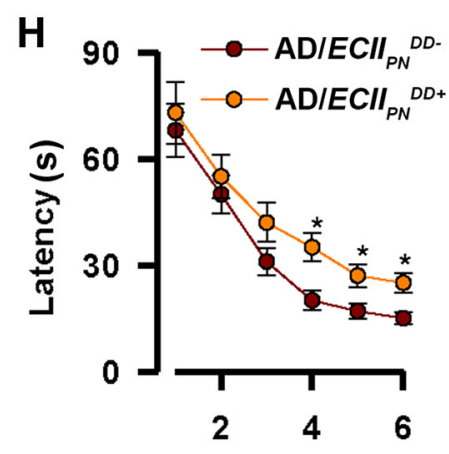

Training of Days

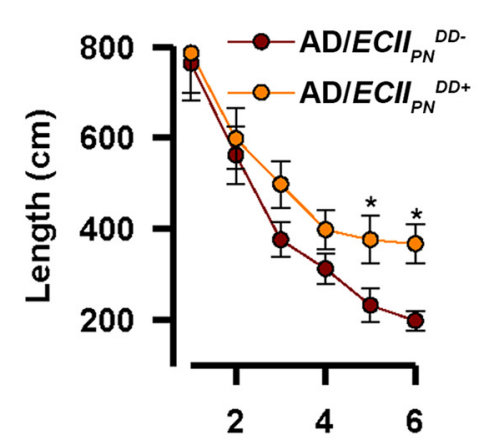

Training of Days

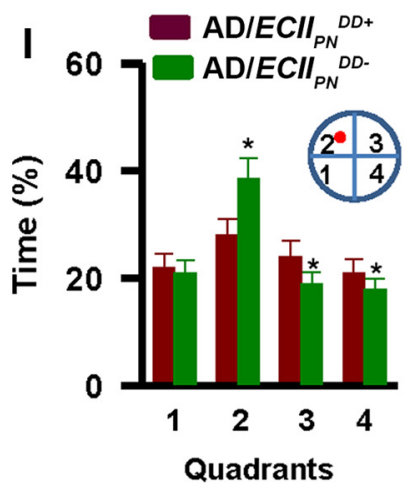

Figure 4. Inhibition of DAPK1 in the ECII ${ }_{P N}$ improves spatial learning and memory in AD mice. $\boldsymbol{A}-\boldsymbol{C}$, The latency $(\boldsymbol{A}, \boldsymbol{B})$ and swim length $(\boldsymbol{C})$ to reach a hidden platform are plotted against the blocks of trials. $\boldsymbol{A}$, Representative path tracings were taken during the training tests on day 6. Data are mean \pm SEM $\left(n=11\right.$ mice per group, $\left.F_{(5,60)}=2.71\right)$. ${ }^{*} p<0.001($ ANOVA). $D-G$, The percentage of time spent in search of a hidden platform in each quadrant during the probe trial of mice at $90(\boldsymbol{D}, \boldsymbol{E}), 120(\boldsymbol{F})$, and $180(\boldsymbol{G})$ days old of age. $\boldsymbol{D}$, Representative hot spot of path tracings taken during the probe trials on day 8. Data are mean $\pm \mathrm{SEM}\left(n=11\right.$ mice per group, $\left.F_{(5,60)}=3.97\right) .{ }^{*} p<0.001$. $\boldsymbol{H}$, Deletion of DAPK1 DD in the ECII PN of AD mice improves spatial information acquisition. The latency and swim length to reach a hidden platform are plotted against the blocks of trials. Data are mean $\pm S E M\left(n=11\right.$ mice per group, $\left.F_{(5,60)}=4.13\right)$. ${ }^{*} p<0.001$. $I$, Deletion of DAPK1 DD in the $E C I_{P N}$ of AD mice improves spatial memory. The percentage of time spent in search of a hidden platform in each quadrant during the probe trial. Data are mean \pm SEM ( $n=11$ mice per group, $\left.F_{(5,60)}=3.11\right) .{ }^{*} p<0.001$.

but this deletion blocked the binding of DAPK1 to DAPK1 substrates, such as the Tau and ERK proteins (Fig. $2 J$ ).

Protection against $\mathrm{ECII}_{\mathrm{PN}}$ synaptic decay in $\mathrm{AD}$ mice

To determine whether the genetic inhibition of DAPK1 might avert the $\mathrm{ECII}_{\mathrm{PN}}$ synaptic decay in $\mathrm{AD}$ mice, we performed whole-cell patch-clamp recordings with the $\mathrm{CA}_{\mathrm{PV}}$ (Fig. $3 A$ ) from the $\mathrm{AD} / E C I I_{P N}{ }^{C D-}$ and $\mathrm{AD} / E C I_{P N}{ }^{D D-}$ mice at $180 \pm 5 \mathrm{~d}$ of age as well as age-matched controls $\left(\mathrm{AD} / E C I I_{P N}{ }^{C h R 2+}\right.$, the control/ECII ${ }_{P N}{ }^{D D-}$, and the control/ECII ${ }_{P N} C h R 2+$ mice). EPSCs were evoked by delivering blue laser light directly to the $\mathrm{ECII}_{\mathrm{PN}}{ }^{\mathrm{ChR} 2+}$ in brain slices. To exclude disturbances from other projections (i.e., the $\mathrm{ECII}_{\mathrm{PN}}-\mathrm{DG}-\mathrm{CA} 3-\mathrm{CA} 1_{\mathrm{PV}}$ indirect pathway), we cut off the connections of the dentate gyrus to the CA3 cells in the slices (Fig. 3A) and recorded NMDA-mediated EPSCs at a holding potential of $60 \mathrm{mV}$. The recordings were performed in the pres- 

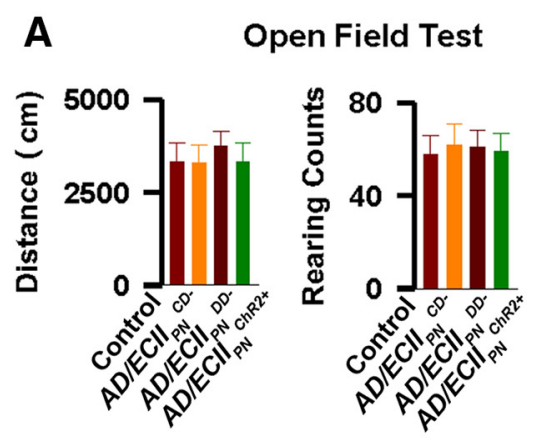

C

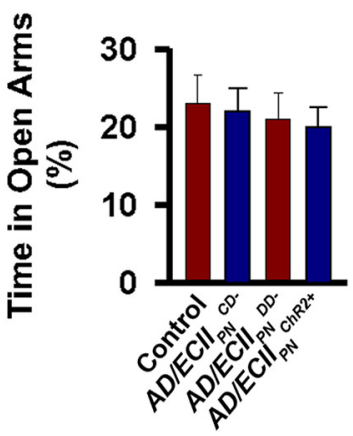

Elevated Plus Maze
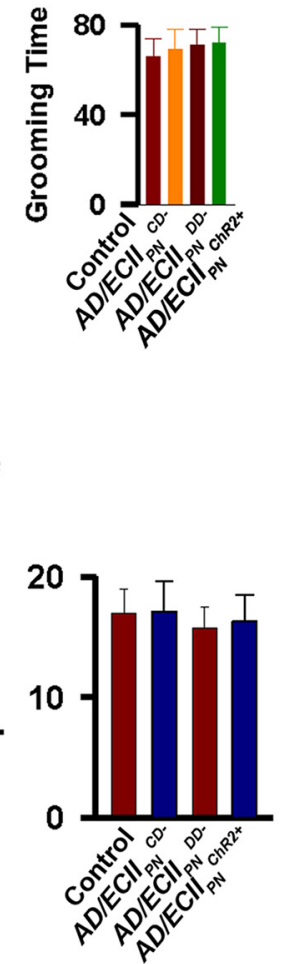

B Rotarod Tests
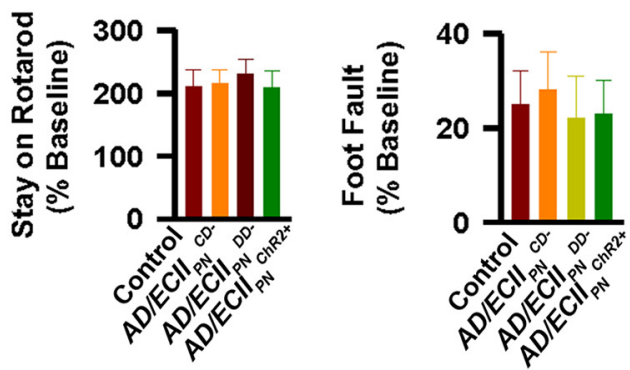

D Forced Swimming
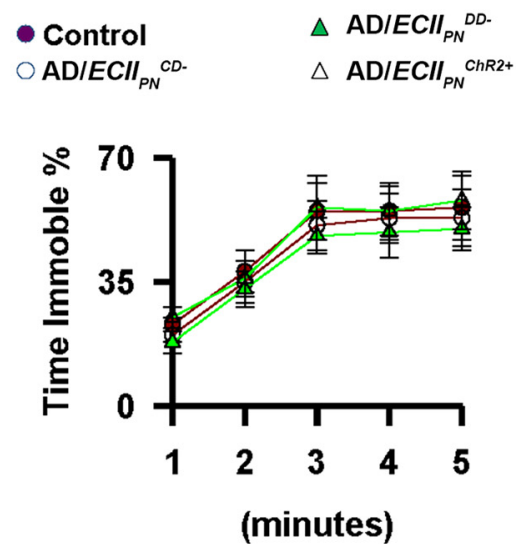

Figure 5. AD mice are normal in learning-unrelated behavioral tests. $\boldsymbol{A}$, Bar graphs represent that distance moved, rearing counts, and grooming time in the open field tests are identical among groups (mean \pm SEM, $n=9$ mice per group). $B$, Bar graphs represent that the performance for foot stay and fault on rotarod tests is comparable between genotypes (mean \pm SEM, $n=8$ mice per group). C, Mice are normal in elevated plus maze tests. Bar graphs represent that time in open arms is identical between groups (mean \pm SEM, $n=9$ mice per group). $\boldsymbol{D}$, Mice are normal in the forced swimming tests. The percentage of time immobile per minute over the whole 5 min trial is identical between groups (mean \pm SEM, $n=9$ mice per group).

ence of $20 \mu \mathrm{M} C N Q X$ and $20 \mu \mathrm{M}$ bicuculline to block both AMPA receptors and Type $\mathrm{A} \mathrm{GABA}_{\mathrm{A}}$ receptor-mediated responses. Under this circumstance, we were able to record monosynaptic transmission between $\mathrm{ECII}_{\mathrm{PN}}$ and $\mathrm{CA} 1_{\mathrm{PV}}$ cells in the slices. We then analyzed the mean amplitudes of the evoked EPSCs with the increases of the stimulus intensities (Fig. 3A). We demonstrated that the genetic inhibition of DAPK1 specifically in the $\mathrm{ECII}_{\mathrm{PN}}$ did not alter synaptic transmission in the control mice (the peak values of the mean amplitudes were $99 \pm 13 \mathrm{pA}$ in the control/ECII ${ }_{P N}^{C h R 2+}$ mice vs $92 \pm 15 \mathrm{pA}$ in the control/ $E C I I_{P N}{ }^{C D-}$ mice), but it was effective in reversing the $\mathrm{ECII}_{\mathrm{PN}^{-}}$ $\mathrm{CA} 1_{\mathrm{PV}}$ synaptic decline in the $\mathrm{AD}$ mice (peak values of the mean amplitudes were $65 \pm 8 \mathrm{pA}$ in the $\mathrm{AD} / E C I I_{P N}{ }^{C h R 2+}$ mice vs $93 \pm$ $9 \mathrm{pA}$ in the $\mathrm{AD} / E C I_{P N}{ }^{C D-}$ mice).

Next, we examined the structure of $\mathrm{ECII}_{\mathrm{PN}}-\mathrm{CA}_{\mathrm{PV}}$ synapses in the $\mathrm{AD} / E C I I_{P N}{ }^{C D-}$ mice (Fig. $3 B$ ). At presynaptic sites, the excitatory terminals in the stratum lacunosum-moleculare, an afferent axon terminal zone of the $\mathrm{ECII}_{\mathrm{PN}}{ }^{\mathrm{ChR} 2+}$ in the CA1 hippocampus, were analyzed (Fig. $3 B$ ). The density of ChR2-eGFPlabeled terminals $(50 \mu \mathrm{m} \times 200 \mu \mathrm{m})$ in the AD mice at $180 \pm 5 \mathrm{~d}$ of age was $29.1 \pm 3.2 \%$ lower than that of the age-matched controls (Fig. 3C). This reduction in the number of excitatory synaptic terminals in the the stratum lacunosum-moleculare region of the $\mathrm{AD}$ mice was completely rescued in both the $\mathrm{AD}$ / $E C I I_{P N}{ }^{C D-}$ and $\mathrm{AD} / E C I I_{P N}{ }^{D D-}$ mice (Fig. 3C). At postsynaptic sites, we stained the sections with an antibody against the PV protein (Fig. $3 B$ ), which revealed that the dendritic branch spines (50 $\mu \mathrm{m}$ segment) from the antibody-labeled $\mathrm{CA} 1_{\mathrm{PV}}$ cells $(50 \mathrm{seg}-$ ments per animal) in the stratum lacunosum-moleculare region of the AD mice decreased by $35.1 \pm 3.9 \%$ compared with those in the age-matched controls $(5.3 \pm 0.63$ vs $3.3 \pm 0.36$, mean $\pm \mathrm{SEM}$, $n=50$ dendritic branches $/ 5$ mice/group, $p<0.001$; Fig. $3 C)$. The inhibition of DAPK1 completely rescued the synaptic loss of the $\mathrm{CA} 1_{\mathrm{PV}}$ in the $\mathrm{AD}$ mice $\left(5.1 \pm 0.59\right.$ in the $\mathrm{AD} / E C I I_{P N}{ }^{C D-}$ mice, $4.9 \pm 0.62$ in the $\mathrm{AD} / E C I I_{P N}{ }^{D D-}$ mice vs $5.2 \pm 0.58$ in the controls, mean \pm SEM, $n=50$ dendritic branches $/ 5$ mice/group, $p>$ 0.05; Fig. 3C).

Impairments of synaptic transmission along the $\mathrm{ECII}_{\mathrm{PN}^{-}}$ $\mathrm{CA} 1_{\mathrm{PV}}$ excitatory pathway, which primarily target the dendrites of CA1 excitatory pyramidal neurons $\left(\mathrm{CA}_{\mathrm{PN}}\right)$ disrupt the excitatory and inhibitory balance in the CA1 neural circuits of $\mathrm{AD}$ mice (Lesne et al., 2006; Mucke, 2007; Palop and Mucke, 2009). Therefore, protecting the $\mathrm{ECII}_{\mathrm{PN}}-\mathrm{CA} 1_{\mathrm{PV}}$ pathway from synaptic loss in $\mathrm{AD}$ mice should restore the excitatory and inhibitory balance in the CA1 circuits (Fig. 3D-F). To test this hypothesis, we monitored the activity of CA1 neuronal cells in freely moving mice at $180 \pm 5 \mathrm{~d}$ of age by using extracellular single-unit recording techniques (Yang et al., 2016). Action potentials that originated from the $C A 1_{P N}$ versus the $C A 1_{P V}$ of freely moving mice were classified on the basis of the properties of the action potential, as recently described (Yang et al., 2016). In the AD mice, the probability of action potential firing was dramatically reduced in the $\mathrm{CA}_{\mathrm{PV}}(11.8 \pm 1.6$ vs $16.9 \pm 1.9$, mean $\pm \mathrm{SEM}, n=36$ units $/ 9$ mice/group, $p<0.001$; Fig. $3 G)$ and increased in the $C A 1_{\mathrm{PN}}$ ( $5.6 \pm 0.68$ vs $3.3 \pm 0.51$, mean $\pm \mathrm{SEM}, n=36$ units $/ 9$ mice/ group, $p<0.001$; Fig. $3 H)$, compared with the age-matched 
control mice, thus showing that the excitatory and inhibitory balance was disrupted in the CA1 circuits of the AD mice. In the $\mathrm{AD} / E C I I_{P N}{ }^{C D-}$ mice, in which DAPK1 was inactivated specifically in the $\mathrm{ECII}_{\mathrm{PN}}$, the excitatory and inhibitory balance in the CA1 circuits was restored; the probabilities of action potential firings in both the $\mathrm{CAl}_{\mathrm{PV}}(16.2 \pm 1.8$ vs $17.5 \pm 1.8$, mean $\pm \mathrm{SEM}$, $n=36$ units $/ 9$ mice/group, $p>0.05)$ and the $C A 1_{\mathrm{PN}}(3.7 \pm 0.52$ vs $3.7 \pm 0.58$, mean \pm SEM, $n=36$ units/9 mice/group, $p>0.05$; Fig. $3 H, G$ ) were identical to those in the age-matched controls. In the $\mathrm{AD} / E C I I_{P N}{ }^{D D-}$ mice, action potential firing in both the $\mathrm{CAl}_{\mathrm{PV}}$ and $C A 1_{\mathrm{PN}}$ was comparable with that in the age-matched controls. Together, these data demonstrate that the inhibition of DAPK1 by selective deletion of either the DAPK1 CD or DAPK1 DD within the $\mathrm{ECII}_{\mathrm{PN}}$ prevents the decay of the $\mathrm{ECII}_{\mathrm{PN}}-\mathrm{CA} 1_{\mathrm{PV}}$ synaptic transmission and hence restores the excitatory and inhibitory balance in the $\mathrm{CA} 1$ circuits of the $\mathrm{AD}$ mice.

\section{Improvements in spatial learning and memory in $\mathrm{AD}$ mice}

We next determined whether preventing the synaptic impairments via the inhibition of DAPK1 in the $\mathrm{ECII}_{\mathrm{PN}}$ improves spatial learning and memory in the $\mathrm{AD}$ mice. We analyzed the task performance of mice at $180 \pm 5 \mathrm{~d}$ of age in a hidden version of the Morris Water Maze test. The $\mathrm{AD} / E C I I_{P N}{ }^{C D-}$ mice showed better performance in all the measured indices (Fig. 4A-G); the latency and swim length to reach a hidden platform during the training session (Fig. 4A-G), and the percentage of time spent in search of a hidden platform in each quadrant during the probe trial (Fig. $4 D-G$ ) were comparable between the $\mathrm{AD} / E C I_{P N}{ }^{C D-}$ mice (latency $=16.9 \pm 1.7 \mathrm{~s}$; length $=192 \pm 21 \mathrm{~cm}$; percentage time $=$ $37 \pm 3.5$ ) and the control AD/ECII ${ }_{P N}{ }^{C D+}$ mice (latency $=15.7 \pm$ $1.3 \mathrm{~s}$; length $=183 \pm 19 \mathrm{~cm}$; percentage time $=35.5 \pm 3.6$ ). These data indicate that the inhibition of DAPK1 effectively averts the decay of spatial learning and memory in the AD mice. Consistently with this conclusion, the $\mathrm{AD} / E C I I_{P N}{ }^{D D-}$ mice with a deletion of the DAPK1 DD in the $\mathrm{ECII}_{\mathrm{PN}}$ also exhibited significant improvements in acquiring spatial information during the Morris Water Maze tests (latency $=15.0 \pm 1.6 \mathrm{~s}$; length $=191 \pm$ $18 \mathrm{~cm}$; percentage time $=38 \pm 3.2$ in the $\mathrm{AD} / E C I I_{P N}{ }^{D D-}$ mice vs latency $=17.1 \pm 1.6 \mathrm{~s}$; length $=189 \pm 20 \mathrm{~cm}$; percentage time $=$ $34.9 \pm 3.3$ in the $\mathrm{AD} / E C I_{P N}{ }^{C h R 2+}$ mice; Fig. $\left.4 H, I\right)$. To determine the specific effects of DAPK1 inhibition on spatial learning and memory, we also performed learning-unrelated behavioral tests, including open field, rotarod, elevated plus maze, and forced swimming. Our data revealed that all the groups of mice, including the AD mice at $180 \pm 5 \mathrm{~d}$ of age, performed normally in all of the learning-unrelated tests, compared with the agematched controls (Fig. 5A-D).

\section{Discussion}

$\mathrm{ECII}_{\mathrm{PN}}$ are some of the earliest affected brain cells in $\mathrm{AD}$, and the selective expression of human mutant APP in the $\mathrm{ECII}_{\mathrm{PN}}$ of mice impairs spatial learning and memory (Harris et al., 2010). Consistently, our data revealed that DAPK1 was selectively activated in the $\mathrm{ECII}_{\mathrm{PN}}$ of $\mathrm{AD}$ mice and that the genetic inhibition of DAPK1 effectively protected against impairments in the $\mathrm{ECII}_{\mathrm{PN}^{-}}$ $\mathrm{CAl}_{\mathrm{PV}}$ synaptic transmission and improved spatial learning and memory.

The key findings in the present study include the following: (1) DAPK1 is selectively activated in ECII $_{\mathrm{PN}}$ in the early stages of AD mice; and (2) the specific inhibition of DAPK1 in the $\mathrm{ECII}_{\mathrm{PN}}$ of AD mice results in therapeutic effects against declines in spatial learning and memory. DAPK1 is a $\mathrm{Ca}^{2+}$ / calmodulin-dependent protein kinase and was originally identified by functional cloning on the basis of its involvement in interferon- $\gamma$-induced apoptosis (Shohat et al., 2001). Previously, we have reported that DAPK1 is activated in central neurons and contributes to neuronal death (Tu et al., 2010). More recently, we have reported that activated DAPK1 directly binds and phosphorylates the Tau protein on Ser262 and induces synaptic degeneration (Pei et al., 2015). Hyperphosphorylation of Tau (tau inclusions, $p$ Tau) results in the self-assembly of tangles of paired helical filaments and straight filaments in the brain, which are involved in the early pathogenesis of AD (Alonso et al., 2001; Clavaguera et al., 2009; Hoover et al., 2010; de Calignon et al., 2012; Spires-Jones and Hyman, 2014). In the present study, we found that genetic deletion of the DAPK1 DD in the $\mathrm{AD} / E C I I_{P N}{ }^{D D-}$ mice disrupted binding of DAPK1 to the Tau protein in $\mathrm{ECII}_{\mathrm{PN}}$. Thus, the DAPK1-Tau interaction may be a crucial signaling event underlying the early degeneration of excitatory synaptic transmission at $\mathrm{ECII}_{\mathrm{PN}}-\mathrm{CA} 1_{\mathrm{PV}}$ synapses and may be a promising target for therapeutic interventions to treat disease progression.

The present study analyzed task performance in a hidden version of the Morris Water Maze test and revealed that $\mathrm{AD}$ mice exhibit spatial learning and memory defects beginning at 6 months of age (Hsiao et al., 1996; Langston et al., 2010). Previous studies have reported that AD mice show deficits in task performance at 9 months of age (Hsiao et al., 1996) or after 14 months of age (Holcomb et al., 1999). However, several other studies have described the presence of behavioral deficits in AD mice as early as 3-6 months of age (King and Arendash, 2002; Lindner et al., 2006; Fritsch et al., 2010). The discrepancies among these studies may be due to differences in the experimental paradigms and in the genetic backgrounds of the mice used in the different laboratories. For example, some studies used a training schedule with 9 trials per day for $6 \mathrm{~d}$, whereas others applied 10 trials per day for $4 \mathrm{~d}$. The genetic background of the AD mice also affects the outcome of behavioral tests. In the present study, the AD mice and the nontransgenic controls were housed under the same conditions and were derived from the same litters; therefore, these parameters should not affect our conclusion that the activation of DAPK1 in $\mathrm{ECII}_{\mathrm{PN}}$ contributes to impairments in spatial learning and memory in $\mathrm{AD}$ mice.

\section{References}

Alonso A, Zaidi T, Novak M, Grundke-Iqbal I, Iqbal K (2001) Hyperphosphorylation induces self-assembly of $\tau$ into tangles of paired helical filaments/straight filaments. Proc Natl Acad Sci USA 98:6923-6928. CrossRef Medline

Chapman PF, White GL, Jones MW, Cooper-Blacketer D, Marshall VJ, Irizarry M, Younkin L, Good MA, Bliss TV, Hyman BT, Younkin SG, Hsiao KK (1999) Impaired synaptic plasticity and learning in aged amyloid precursor protein transgenic mice. Nat Neurosci 2:271-276. CrossRef Medline

Clavaguera F, Bolmont T, Crowther RA, Abramowski D, Frank S, Probst A, Fraser G, Stalder AK, Beibel M, Staufenbiel M, Jucker M, Goedert M, Tolnay M (2009) Transmission and spreading of tauopathy in transgenic mouse brain. Nat Cell Biol 11:909-913. CrossRef Medline

de Calignon A, Polydoro M, Suárez-Calvet M, William C, Adamowicz DH, Kopeikina KJ, Pitstick R, Sahara N, Ashe KH, Carlson GA, Spires-Jones TL, Hyman BT (2012) Propagation of tau pathology in a model of early Alzheimer's disease. Neuron 73:685-697. CrossRef Medline

Duffy AM, Morales-Corraliza J, Bermudez-Hernandez KM, Schaner MJ, Magagna-Poveda A, Mathews PM, Scharfman HE (2015) Entorhinal cortical defects in Tg2576 mice are present as early as 2-4 months of age. Neurobiol Aging 36:134-148. CrossRef Medline

Fritsch B, Reis J, Martinowich K, Schambra HM, Ji Y, Cohen LG, Lu B (2010) 
Direct current stimulation promotes BDNF-dependent synaptic plasticity: potential implications for motor learning. Neuron 66:198-204. CrossRef Medline

Goate A, Chartier-Harlin MC, Mullan M, Brown J, Crawford F, Fidani L, Giuffra L, Haynes A, Irving N, James L (1991) Segregation of a missense mutation in the amyloid precursor protein gene with familial Alzheimer's disease. Nature 349:704-706. CrossRef Medline

Gómez-Isla T, Price JL, McKeel DW Jr, Morris JC, Growdon JH, Hyman BT (1996) Profound loss of layer II entorhinal cortex neurons occurs in very mild Alzheimer's disease. J Neurosci 16:4491-4500. Medline

Harris JA, Devidze N, Verret L, Ho K, Halabisky B, Thwin MT, Kim D, Hamto P, Lo I, Yu GQ, Palop JJ, Masliah E, Mucke L (2010) Transsynaptic progression of amyloid- $\beta$-induced neuronal dysfunction within the entorhinalhippocampal network. Neuron 68:428-441. CrossRef Medline

Holcomb LA, Gordon MN, Jantzen P, Hsiao K, Duff K, Morgan D (1999) Behavioral changes in transgenic mice expressing both amyloid precursor protein and presenilin- 1 mutations: lack of association with amyloid deposits. Behav Genet 29:177-185. CrossRef Medline

Hoover BR, Reed MN, Su J, Penrod RD, Kotilinek LA, Grant MK, Pitstick R, Carlson GA, Lanier LM, Yuan LL, Ashe KH, Liao D (2010) Tau mislocalization to dendritic spines mediates synaptic dysfunction independently of neurodegeneration. Neuron 68:1067-1081. CrossRef Medline

Hsia AY, Masliah E, McConlogue L, Yu GQ, Tatsuno G, Hu K, Kholodenko D, Malenka RC, Nicoll RA, Mucke L (1999) Plaque-independent disruption of neural circuits in Alzheimer's disease mouse models. Proc Natl Acad Sci U S A 96:3228-3233. CrossRef Medline

Hsiao K, Chapman P, Nilsen S, Eckman C, Harigaya Y, Younkin S, Yang F, Cole G (1996) Correlative memory deficits, Abeta elevation, and amyloid plaques in transgenic mice. Science 274:99-102. CrossRef Medline

Jack CR Jr, Knopman DS, Jagust WJ, Shaw LM, Aisen PS, Weiner MW, Petersen RC, Trojanowski JQ (2010) Hypothetical model of dynamic biomarkers of the Alzheimer's pathological cascade. Lancet Neurol 9:119-128. CrossRef Medline

Jacobsen JS, Wu CC, Redwine JM, Comery TA, Arias R, Bowlby M, Martone R, Morrison JH, Pangalos MN, Reinhart PH, Bloom FE (2006) Earlyonset behavioral and synaptic deficits in a mouse model of Alzheimer's disease. Proc Natl Acad Sci U S A 103:5161-5166. CrossRef Medline

Kamenetz F, Tomita T, Hsieh H, Seabrook G, Borchelt D, Iwatsubo T, Sisodia S, Malinow R (2003) APP processing and synaptic function. Neuron 37:925-937. CrossRef Medline

King DL, Arendash GW (2002) Behavioral characterization of the Tg2576 transgenic model of Alzheimer's disease through 19 months. Physiol Behav 75:627-642. CrossRef Medline

Kitamura T, Pignatelli M, Suh J, Kohara K, Yoshiki A, Abe K, Tonegawa S (2014) Island cells control temporal association memory. Science 343: 896-901. CrossRef Medline
Langston RF, Ainge JA, Couey JJ, Canto CB, Bjerknes TL, Witter MP, Moser EI, Moser MB (2010) Development of the spatial representation system in the rat. Science 328:1576-1580. CrossRef Medline

Lesné S, Koh MT, Kotilinek L, Kayed R, Glabe CG, Yang A, Gallagher M, Ashe $\mathrm{KH}$ (2006) A specific amyloid-beta protein assembly in the brain impairs memory. Nature 440:352-357. CrossRef Medline

Lindner MD, Hogan JB, Krause RG, Machet F, Bourin C, Hodges DB Jr, Corsa JA, Barten DM, Toyn JH, Stock DA, Rose GM, Gribkoff VK (2006) Soluble $\mathrm{A} \beta$ and cognitive function in aged F-344 rats and Tg2576 mice. Behav Brain Res 173:62-75. CrossRef Medline

Oddo S, Caccamo A, Shepherd JD, Murphy MP, Golde TE, Kayed R, Metherate R, Mattson MP, Akbari Y, LaFerla FM (2003) Triple-transgenic model of Alzheimer's disease with plaques and tangles: intracellular $\mathrm{A} \beta$ and synaptic dysfunction. Neuron 39:409-421. CrossRef Medline

Palop JJ, Mucke L (2009) Epilepsy and cognitive impairments in Alzheimer disease. Arch Neurol 66:435-440. CrossRef Medline

Pei L, Wang S, Jin H, Bi L, Wei N, Yan H, Yang X, Yao C, Xu M, Shu S, Guo Y, Yan H, Wu J, Li H, Pang P, Tian T, Tian Q, Zhu LQ, Shang Y, Lu Y (2015) A novel mechanism of spine damages in stroke via DAPK1 and tau. Cereb Cortex 25:4559-4571. CrossRef Medline

Scheff SW, Price DA, Schmitt FA, DeKosky ST, Mufson EJ (2007) Synaptic alterations in CA1 in mild Alzheimer disease and mild cognitive impairment. Neurology 68:1501-1508. CrossRef Medline

Shohat G, Spivak-Kroizman T, Cohen O, Bialik S, Shani G, Berrisi H, Eisenstein M, Kimchi A (2001) The pro-apoptotic function of death-associated protein kinase is controlled by a unique inhibitory autophosphorylation-based mechanism. J Biol Chem 276:47460-47467. CrossRef Medline

Spires-Jones TL, Hyman BT (2014) The intersection of amyloid beta and tau at synapses in Alzheimer's disease. Neuron 82:756-771. CrossRef Medline

Tanzi RE, Gusella JF, Watkins PC, Bruns GA, St George-Hyslop P, Van Keuren ML, Patterson D, Pagan S, Kurnit DM, Neve RL (1987) Amyloid beta protein gene: $\mathrm{CDNA}, \mathrm{mRNA}$ distribution, and genetic linkage near the Alzheimer locus. Science 235:880-884. CrossRef Medline

Tu W, Xu X, Peng L, Zhong X, Zhang W, Soundarapandian MM, Balel C, Wang M, Jia N, Zhang W, Lew F, Chan SL, Chen Y, Lu Y (2010) DAPK1 interaction with NMDA receptor NR2B subunits mediates brain damage in stroke. Cell 140:222-234. CrossRef Medline

Yang X, Yao C, Tian T, Li X, Yan H, Wu J, Li H, Pei L, Liu D, Tian Q, Zhu IQ, LuY (2016) A novel mechanism of a memory loss in Alzheimer's disease mice via degeneration of entorhinal-CA1 synapses. Mol Psychiatry, in press.

Yassa MA (2014) Ground zero in Alzheimer's disease. Nat Neurosci 17: 146-147. CrossRef Medline 